Article

\title{
New Biflavonoids with $\alpha$-Glucosidase and Pancreatic Lipase Inhibitory Activities from Boesenbergia rotunda
}

\author{
Nutputsorn Chatsumpun ${ }^{\dagger}$, Boonchoo Sritularak and Kittisak Likhitwitayawuid * \\ Department of Pharmacognosy and Pharmaceutical Botany, Faculty of Pharmaceutical Sciences, \\ Chulalongkorn University, Bangkok 10330, Thailand; manee_many@hotmail.com (N.C.); \\ Boonchoo.Sr@chula.ac.th (B.S.) \\ * Correspondence: Kittisak.L@chula.ac.th; Tel.: +66-2-218-8360 \\ † Present address: Department of Pharmacognosy, Faculty of Pharmacy, Mahidol University, \\ Bangkok 10400, Thailand.
}

Received: 17 October 2017; Accepted: 25 October 2017; Published: 30 October 2017

\begin{abstract}
Roots of Boesenbergia rotunda (L.) Mansf. are prominent ingredients in the cuisine of several Asian countries, including Thailand, Malaysia, Indonesia, India, and China. An extract prepared from the roots of this plant showed strong inhibitory activity against enzymes $\alpha$-glucosidase and pancreatic lipase and was subjected to chromatographic separation to identify the active components. Three new biflavonoids of the flavanone-chalcone type (9, 12, and 13) were isolated, along with 12 known compounds. Among the 15 isolates, the three new compounds showed stronger inhibitory activity against $\alpha$-glucosidase than the drug acarbose but displayed lower pancreatic lipase inhibitory effect than the drug orlistat. The results indicated the potential of $B$. rotunda roots as a functional food for controlling after-meal blood glucose levels.
\end{abstract}

Keywords: Boesenbergia rotunda; biflavonoid; flavanone-chalcone; cyclohexenyl chalcone; $\alpha$-glucosidase; pancreatic lipase

\section{Introduction}

In recent years, metabolic syndrome (MetS) has gained worldwide attention due to its association with the risk of developing cardiovascular diseases and diabetes. MetS is defined as a cluster of 3 or more metabolic disorders including hypertension, obesity, high-serum triglycerides, low level of high-density lipoprotein and hyperglycemia [1,2]. Analysis of the data obtained from MetS patients has revealed the frequent co-occurrence of dyslipidemia and hyperglycemia although their cause-effect relationships are not yet understood [3]. Dietary manipulation is one of the approaches suggested for controlling MetS. Recent research has shown that botanical dietary supplements may serve as preventive agents of MetS because they usually contain structurally diverse, biologically active compounds with multiple mechanisms of action and potentially synergistic effects. Herbs with therapeutic promise for MetS have been found in various plant families, including both monocotyledons and dicotyledons, and their chemical compositions have been identified and classified as flavonoids, steroids, and triterpenoids [4]. $\alpha$-glucosidase is an enzyme responsible for the breaking down of starch and disaccharides into glucose for intestinal uptake, whereas pancreatic lipase plays a key role in lipid absorption by hydrolyzing triglycerides into glycerol and free fatty acids. Plant extracts or phytochemicals that can inhibit the two enzymes are viewed as beneficial for the regulation of serum levels of sugar and fat. The present study attempted to find edible plants that may be used as functional foods in controlling postprandial hyperglycemia and hyperlipidemia.

Boesenbergia rotunda (L.) Mansf. (Zingiberaceae) (B. rotunda) is a culinary herb prominently featured in Thai cuisine, as well as in the dishes of several other Asian countries, including Malaysia, 
Indonesia, India, and China. The plant is commonly known as "Chinese ginger" or "fingerroot"; the latter name comes from the shape of its roots resembling fingers. In Thailand, B. rotunda, or "Krachai", is widely cultivated for roots that are usually used as a common condiment in food such as soup or an ingredient in dipping sauce [5]. In addition, the roots are also believed to have a sexually enhancing property and often included in aphrodisiac recipes and referred to as "Thai ginseng". Several in vivo experiments on the aphrodisiac activity of this plant have been reported [6].

B. rotunda has several botanical synonyms, including Boesenbergia cochinchinensis (Gagnep.) Loes., Boesenbergia pandurata (Roxb.) Schltr., Curcuma rotunda L., Gastrochilus panduratus (Roxb.) Ridl., Gastrochilus rotundus (L.) Alston, Kaempferia cochinchinensis Gagnep., Kaempferia ovata Roscoe, and Kaempferia pandurata Roxb. [7]. Previous chemical and biological studies on this plant have revealed the presence of flavonoids, styryl pyrones, and terpenoids, as well as a wide range of biological activities [8]. A recent report has suggested the potential use of this plant for the treatment of obesity [9]. During our preliminary screening of household vegetables for inhibitory activity against $\alpha$-glucosidase and pancreatic lipase, we found that a methanol extract of $B$. rotunda showed strong inhibition of both enzymes $(100 \%$ inhibition at $100 \mu \mathrm{g} / \mathrm{mL})$. This prompted us to investigate this plant to determine the active principles, as well as their enzyme inhibition mechanisms.

\section{Results and Discussion}

\subsection{Structure Elucidation of Bioactive Components}

The methanol $(\mathrm{MeOH})$ extract of the roots of Boesenbergia rotunda was treated with $\mathrm{CH}_{2} \mathrm{Cl}_{2}$. The $\mathrm{CH}_{2} \mathrm{Cl}_{2}$ soluble fraction $(50 \mu \mathrm{g} / \mathrm{mL})$ exhibited strong inhibition against both $\alpha$-glucosidase and lipase enzymes, but the $\mathrm{CH}_{2} \mathrm{Cl}_{2}$ insoluble fraction showed no activity. Separation of the $\mathrm{CH}_{2} \mathrm{Cl}_{2}$ extract through repeated column chromatography gave three new compounds $(9,12$, and 13), along with 12 known compounds which included four flavanones $(\mathbf{1}, \mathbf{5}, \mathbf{1 1}$, and $\mathbf{1 5})$, six chalcones $(\mathbf{3}, \mathbf{4}, \mathbf{6 - 7}, \mathbf{1 0}$, and 14), a monoterpene alcohol (2), and a styrylpyrone or kavalactone (8) (Figure 1).<smiles>[R20]c1cc2c3c(O)cc([R])c(c3c1)O[C@H](c1ccccc1)CC2=O</smiles>

$1 R^{1}=H, R^{2}=M e$ $5 \quad \mathrm{R}^{1}=\mathrm{H}, \mathrm{R}^{2}=\mathrm{H}$ $11 \mathrm{R}^{1}=\mathrm{Me}, \mathrm{R}^{2}=\mathrm{H}$<smiles>COc1cc(/C=C/c2ccccc2)oc(=O)c1</smiles>

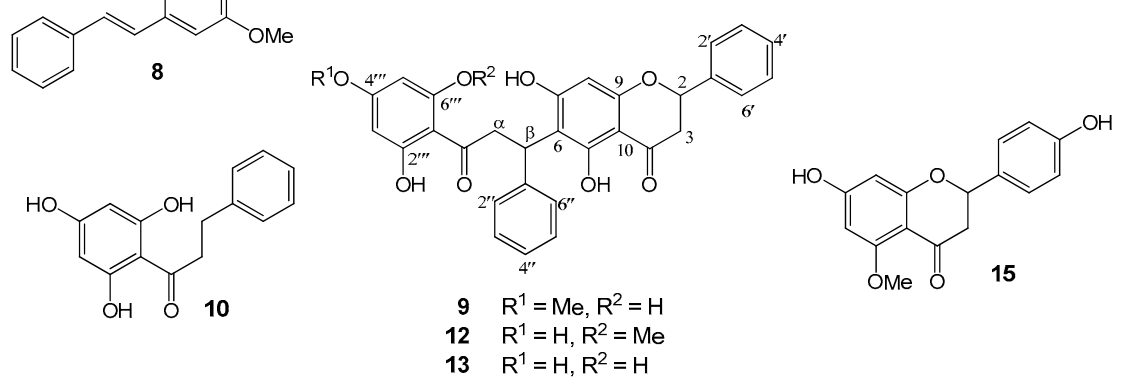<smiles>CC(C)=CCC/C(C)=C/CO</smiles><smiles>[R]c1ccc(C=CC(=O)c2c(O)cc(O)cc2O)cc1</smiles>

$\begin{array}{rl}6 \mathrm{R} & =\mathrm{H} \\ 14 & \mathrm{R}\end{array}=\mathrm{OH}$

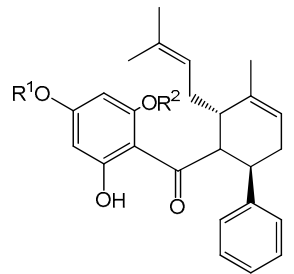

$3 \mathrm{R}^{1}=\mathrm{Me}, \mathrm{R}^{2}=\mathrm{H}$

$4 \mathrm{R}^{1}=\mathrm{H}, \mathrm{R}^{2}=\mathrm{Me}$

$7 \quad \mathrm{R}^{1}=\mathrm{H}, \mathrm{R}^{2}=\mathrm{H}$

Figure 1. Chemical structures of Compounds 1-15 isolated from Boesenbergia rotunda.

Compound 9 was obtained as a pale yellow solid. The $[\mathrm{M}+\mathrm{Na}]^{+}$ion at $m / z 549.1519$ (calcd for $\mathrm{C}_{31} \mathrm{H}_{26} \mathrm{O}_{8} \mathrm{Na} 549.1520$ ) in the high-resolution electrospray ionization mass spectrum (HR-ESI-MS) indicated a molecular formula of $\mathrm{C}_{31} \mathrm{H}_{26} \mathrm{O}_{8}$, suggesting a biflavonoid skeleton. The IR 
spectrum displayed bands for hydroxyl and carbonyl functionalities at 3399 and $1632(\mathrm{C}=\mathrm{O}) \mathrm{cm}^{-1}$, respectively, whereas the UV spectrum exhibited absorptions at 219 and $290 \mathrm{~nm}$, typical of a flavanone or a dihydrochalcone structure. The COSY and HSQC spectra of 9 showed the presence of a methane-methylene coupling system $\left(\delta_{\mathrm{H}} 5.51(1 \mathrm{H}, \mathrm{dd}, J=13.0,2.7 \mathrm{~Hz}, \mathrm{H}-2) / \delta_{\mathrm{C}} 79.9(\mathrm{C}-2) ; \delta_{\mathrm{H}} 3.15(1 \mathrm{H}\right.$, $\mathrm{dd}, J=17.0,13.0 \mathrm{~Hz}, \mathrm{H}-3)$ and $2.74(1 \mathrm{H}, \mathrm{dd}, J=17.0,2.7 \mathrm{~Hz}, \mathrm{H}-3) / \delta_{\mathrm{C}} 43.7$ (C-3)) (Table 1) that were comparable to those observed for pinocembrin (5), a flavanone also isolated in this study. In addition, Compound 9 exhibited another set of aliphatic NMR resonances that could be related to those of $2^{\prime}, 6^{\prime}$-dihydroxy-4'-methoxydihydrochalcone [10], but with $\mathrm{C}-\beta$ appearing as a methine carbon $\left(\delta_{\mathrm{H}}\right.$ 4.05-4.09 (1H, m, H- $\alpha)$, 4.24-4.32 (1H, m, H- $\left.\alpha) / \delta_{\mathrm{C}} 47.1 ; \delta_{\mathrm{H}} 5.33(1 \mathrm{H}, \mathrm{t}, J=7.3 \mathrm{~Hz}, \mathrm{H}-\beta) / \delta_{\mathrm{C}} 35.5\right)$. This was consistent with the DEPT and HSQC data of the flavanone part of 9, which displayed C-6 as a quaternary carbon at $\delta 112.4$. These NMR spectral properties suggested that 9 was a biflavonoid consisting of a flavanone structure connected to a dihydrochalcone unit through a $\mathrm{C}-\mathrm{C}$ bond between C-6 and C- $\beta$. The HMBC correlation of $\mathrm{H}-\beta(\delta 5.33)$ to $\mathrm{C}-5(\delta 163.0)$ and $\mathrm{C}=\mathrm{O}(\delta 205.6)$ confirmed the existence and position of this bridge. In addition, the MeO group at $\delta 3.77$ should be placed at the para-position due to its NOESY correlation peak with the two aromatic protons at $\delta 5.98$. Based on the above-mentioned spectral analyses, 9 was determined to be a biflavonoid derived from flavanone-chalcone coupling, with the structure as shown (Figure 1), and was given the trivial name rotundaflavanochalcone. Compound 9 is the first member of this class of dimeric flavonoids.

Compound 12 was isolated as a light brown solid. The ion $[\mathrm{M}+\mathrm{Na}]^{+}$at $m / z 549.1527$ (calcd for $\left.\mathrm{C}_{31} \mathrm{H}_{26} \mathrm{O}_{8} \mathrm{Na} 549.1520\right)$ in the HR-ESI-MS indicated a molecular formula of $\mathrm{C}_{31} \mathrm{H}_{26} \mathrm{O}_{8}$, which was identical with that of 9. In addition, 12 showed IR bands at $3391(\mathrm{OH}), 2918(\mathrm{C}-\mathrm{H})$, and $1631(\mathrm{C}=\mathrm{O})$ $\mathrm{cm}^{-1}$ and UV absorptions at 220 and 292 (4.33) $\mathrm{nm}$ that were similar to those of 9 . These implied that 12 was an isomer of 9 . Although ${ }^{1} \mathrm{H}$ - and ${ }^{13} \mathrm{C}-\mathrm{NMR}$ signals for the flavanone part of 12 were nearly superimposed with those of 9 (Table 1), the resonances for the dihydrochalcone unit were slightly different. In 12, the acetate-derived aromatic ring of the dihydrochalcone moiety was not symmetrically substituted, as indicated from the distinct chemical shifts observed for $\mathrm{H}-3^{\prime \prime \prime} / \mathrm{C}-3^{\prime \prime \prime}$ $\left(\delta_{\mathrm{H}} 5.92(\mathrm{~d}, J=2.2 \mathrm{~Hz}) / \delta_{\mathrm{C}} 96.8\right)$ and $\mathrm{H}-5^{\prime \prime \prime} / \mathrm{C}-5^{\prime \prime \prime}\left(\delta_{\mathrm{H}} 6.03(\mathrm{br} \mathrm{s}) / \delta_{\mathrm{C}} 91.8\right)$. The MeO group $\left(\delta_{\mathrm{H}} 3.85\right.$ $\left.(3 \mathrm{H}, \mathrm{s}) / \delta_{\mathrm{C}} 56.2\right)$ in 12 was located at C- $6^{\prime \prime \prime}$, as established by the NOESY correlation peak between the $\mathrm{MeO}$ protons and $\mathrm{H}-5^{\prime \prime \prime}$ ( $\left.\delta 6.03\right)$. The HMBC of 12 showed ${ }^{3} J_{\mathrm{CH}}$ couplings between $\mathrm{H}-\beta(\delta 5.26)$ and $C-5$ ( $\delta$ 162.9) and therefore confirmed the C-6 to C- $\beta$ linkage for the flavanone-dihydrochalcone union. Thus, it was concluded $\mathbf{1 2}$ was a structural isomer of $\mathbf{9}$ with the structure as shown, and the compound was named iso-rotundaflavanochalcone.

Table 1. NMR data of Compounds 9, 12, and 13 ( $\delta$ in ppm and $J$ in $\mathrm{Hz}){ }^{\mathrm{a}-\mathrm{c}}$

\begin{tabular}{|c|c|c|c|c|c|c|}
\hline \multirow{2}{*}{ Position } & \multicolumn{2}{|l|}{9} & \multicolumn{2}{|l|}{12} & \multicolumn{2}{|l|}{13} \\
\hline & $\delta_{\mathrm{H}}$ & $\delta_{C}$ & $\delta_{H}$ & $\delta_{C}$ & $\delta_{H}$ & $\delta_{C}$ \\
\hline \multicolumn{7}{|c|}{ Flavanone unit } \\
\hline 2 & $5.51 \mathrm{dd}(13,2.7)$ & 79.9 & $5.52 \mathrm{dd}(13,2.8)$ & 79.9 & $5.52 \mathrm{dd}(13,2.4)$ & 79.9 \\
\hline \multirow[t]{3}{*}{3} & $2.74 \mathrm{dd}(17,2.7)$ & 43.7 & $2.75 \mathrm{dd}(17,2.8)$ & 43.7 & $2.75 \mathrm{dd}(17,2.4)$ & 43.7 \\
\hline & $3.15 \mathrm{dd}(17,13)$ & & $3.15 \mathrm{dd}(17,13)$ & & $3.15 \mathrm{dd}(17,13)$ & \\
\hline & $2.74 \mathrm{dd}(17,2.7)$ & & $2.75 \mathrm{dd},(17,2.8)$ & & $2.75 \mathrm{dd},(17,2.4)$ & \\
\hline 4 & & 197.1 & & 197.1 & & 197.1 \\
\hline 5 & & 163.0 & & 162.9 & & 163.0 \\
\hline 6 & & 112.4 & & 112.5 & & 112.5 \\
\hline 7 & & 162.0 & & 164.5 & & 162.0 \\
\hline 8 & $6.04 \mathrm{~s}$ & 95.7 & $6.04 \mathrm{~s}$ & 95.7 & $6.04 \mathrm{~s}$ & 95.7 \\
\hline 9 & & 165.2 & & 162.0 & & 165.0 \\
\hline 10 & & 103.1 & & 103.1 & & 103.2 \\
\hline 1 & & 140.1 & & 140.1 & & 140.1 \\
\hline $2^{\prime}\left(6^{\prime}\right)$ & $7.08-7.55 \mathrm{~m}$ & 127.3 & $7.06-7.56 \mathrm{~m}$ & 127.3 & $7.06-7.56 \mathrm{~m}$ & 127.3 \\
\hline $3^{\prime}\left(5^{\prime}\right)$ & $7.08-7.55 \mathrm{~m}$ & 129.4 & $7.06-7.56 \mathrm{~m}$ & 128.8 & $7.06-7.56 \mathrm{~m}$ & 128.8 \\
\hline $4^{\prime}$ & $7.08-7.55 \mathrm{~m}$ & 129.4 & $7.06-7.56 \mathrm{~m}$ & 126.3 & $7.06-7.56 \mathrm{~m}$ & 129.4 \\
\hline
\end{tabular}


Table 1. Cont.

\begin{tabular}{|c|c|c|c|c|c|c|}
\hline \multirow{2}{*}{ Position } & \multicolumn{2}{|c|}{9} & \multicolumn{2}{|c|}{12} & \multicolumn{2}{|c|}{13} \\
\hline & $\delta_{\mathbf{H}}$ & $\delta_{\mathrm{C}}$ & $\delta_{\mathbf{H}}$ & $\delta_{C}$ & $\delta_{\mathbf{H}}$ & $\delta_{C}$ \\
\hline \multicolumn{7}{|c|}{ Dihydrochalcone unit } \\
\hline $1^{\prime \prime}$ & & 145.6 & & 145.5 & & 145.7 \\
\hline $2^{\prime \prime}\left(6^{\prime \prime}\right)$ & $7.08-7.55 \mathrm{~m}$ & 128.7 & $7.06-7.56 \mathrm{~m}$ & 129.4 & $7.06-7.56 \mathrm{~m}$ & 129.4 \\
\hline $3^{\prime \prime}\left(5^{\prime \prime}\right)$ & $7.08-7.55 \mathrm{~m}$ & 128.5 & $7.06-7.56 \mathrm{~m}$ & 128.5 & $7.06-7.56 \mathrm{~m}$ & 128.5 \\
\hline $4^{\prime \prime}$ & $7.08-7.55 \mathrm{~m}$ & 126.2 & $7.06-7.56 \mathrm{~m}$ & 129.4 & $7.06-7.56 \mathrm{~m}$ & 126.2 \\
\hline $1^{\prime \prime \prime}$ & & 105.9 & & 106.0 & & 105.4 \\
\hline $2^{\prime \prime \prime}$ & & 165.2 & & 168.2 & & 165.2 \\
\hline $3^{\prime \prime \prime}$ & $5.98 \mathrm{~s}$ & 94.3 & $5.92 \mathrm{~d}(2.2)$ & 96.8 & $5.92 \mathrm{~s}$ & 95.8 \\
\hline $4^{\prime \prime \prime}$ & & 166.6 & & 165.4 & & 165.4 \\
\hline $5^{\prime \prime \prime}$ & $5.98 \mathrm{~s}$ & 94.3 & 6.03 br s & 91.8 & $5.92 \mathrm{~s}$ & 95.8 \\
\hline $6^{\prime \prime \prime}$ & & 165.2 & & 165.1 & & 165.2 \\
\hline $\mathrm{C}=\mathrm{O}$ & & 205.6 & & 205.2 & & 205.2 \\
\hline \multirow[t]{2}{*}{$\alpha$} & $4.05-4.09 \mathrm{~m}$ & 47.1 & $3.80-3.99 \mathrm{~m}$ & 47.3 & $3.98-4.09 \mathrm{~m}$ & 47.0 \\
\hline & $4.24-4.32 \mathrm{~m}$ & & $4.07-4.19 \mathrm{~m}$ & & $4.22-4.30 \mathrm{~m}$ & \\
\hline$\beta$ & 5.33 t (7.3) & 35.5 & 5.26 t $(7.2)$ & 35.8 & 5.33 t (7.3) & 35.5 \\
\hline HO-5 & $12.75 \mathrm{~s}$ & - & $12.76 \mathrm{~s}$ & - & $12.73 \mathrm{~s}$ & - \\
\hline $\mathrm{MeO}-4^{\prime \prime \prime}$ & $3.77 \mathrm{~s}$ & 55.7 & - & - & & - \\
\hline $\mathrm{MeO}-6^{\prime \prime \prime}$ & - & - & $3.85 \mathrm{~s}$ & 56.2 & & - \\
\hline
\end{tabular}

Compound 13 was purified as a light brown solid. It displayed IR bands for $\mathrm{OH}\left(3398 \mathrm{~cm}^{-1}\right)$ and $\mathrm{C}=\mathrm{O}\left(1632 \mathrm{~cm}^{-1}\right)$ functionalities, as well as UV absorptions for a flavanone/dihydrochalcone structure (204 and $291 \mathrm{~nm}$ ). The HR-ESI-MS data displayed $[\mathrm{M}+\mathrm{Na}]^{+}$at $m / z 535.1365$ (calcd for $\mathrm{C}_{30} \mathrm{H}_{24} \mathrm{O}_{8} \mathrm{Na}$ 535.1363), corresponding to the molecular formula $\mathrm{C}_{30} \mathrm{H}_{24} \mathrm{O}_{8}$. The ${ }^{1} \mathrm{H}$ - and ${ }^{13} \mathrm{C}-\mathrm{NMR}$ data of $\mathbf{1 3}$ showed close resemblance to that of $\mathbf{9}$, suggesting a similar flavanone-dihydrochalcone skeleton (Table 1). The only exception was the absence of NMR signals for a MeO group in 13, consistent with its molecular mass being $14 \mathrm{amu}$ lower than that of $\mathbf{9}$. The long-range coupling observed for $\mathrm{H}-\beta$ ( $\delta 5.33)$ and C-5 ( $\delta 163.0)$ in the HMBC spectrum confirmed the connection of C-6 of the flavanone part to $C-\beta$ of the dihydrochalcone unit. Based on the above spectroscopic evidence, $\mathbf{1 3}$ was determined to be the de-O-methyl derivative of $\mathbf{9}$, and therefore named de-O-methyl rotundaflavanochalcone.

The unique structures of the cyclohexenyl chalcones $(3,4$, and 7$)$ and the flavonochalcones $(9,12$, and 13) deserve some discussion on their biogenesis. Both groups can be considered as products of the Michael addition reaction of the chalcone skeleton with a corresponding nucleophile. The former group involves a geranyl-derived diene as the nucleophile attacking the $\alpha, \beta$-unsaturated carbonyl, whereas the latter engages a flavanone molecule as the Michael donor.

The cyclohexenyl chalcones 3,4 , and 7 can be viewed as produced from the prenylation, or more specifically, the geranylation of a chalcone (Figure 2). For example, the biogenesis of 4 can begin with the Michael addition of the chalcone cardamonin (6) with $2 a$, a putative dehydration product of geraniol (2). This then leads to the formation of structure $4 \mathbf{a}$ (path $a$ ), which can subsequently cyclize to give isopanduratin A (4), a cyclohexenyl chalcone. Alternatively, 4 may be formed directly from the $[4+2]$ addition between $2 a$ and $\mathbf{6}$ via Diels-Alder reaction (path $b$ ). Either way, the $\alpha, \beta$-unsaturated carbonyl of the chalcone skeleton is the key starting structure.

An analogous biogenetic pathway can be proposed for the biflavonoids 9, 12, and 13 (Figure 3). For instance, the biogenesis of $\mathbf{1 2}$ can be initiated by the nucleophilic attack from C- 6 of the flavanone pinocembrin (5) onto C- $\beta$ of the chalcone cardamonin (6) to form structure 12a. Through keto-enol tautomerization, 12a isomerizes to generate iso-rotundaflavanochalcone (12). To the best of our knowledge, 9, 12, and 13 are the first representatives of biflavonoids with C-6 (flavanone) to C- $\beta$ (chalcone) linkage. So far, there has been only one other example of flavanone-chalcone-derived biflavonoid, which, however, involves a different type of coupling [11]. 


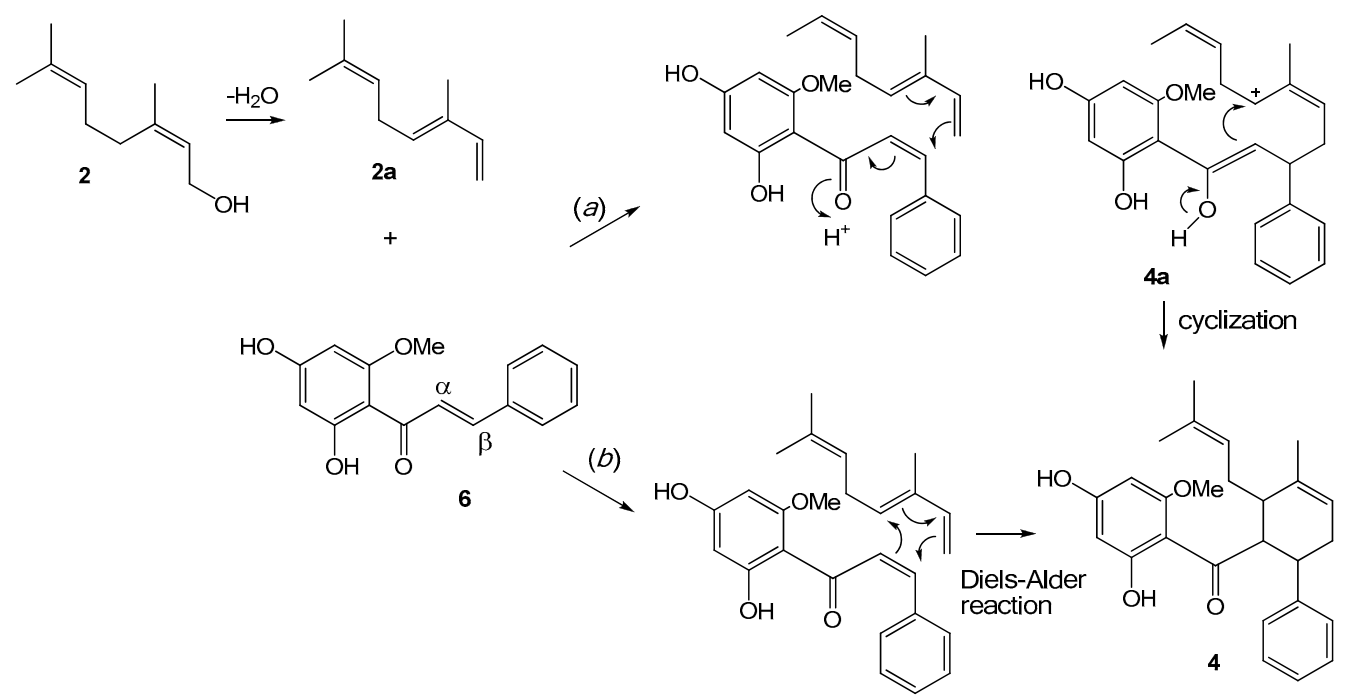

Figure 2. Proposed biogenetic pathway for cyclohexenyl chalcones 3, 4, and 7.
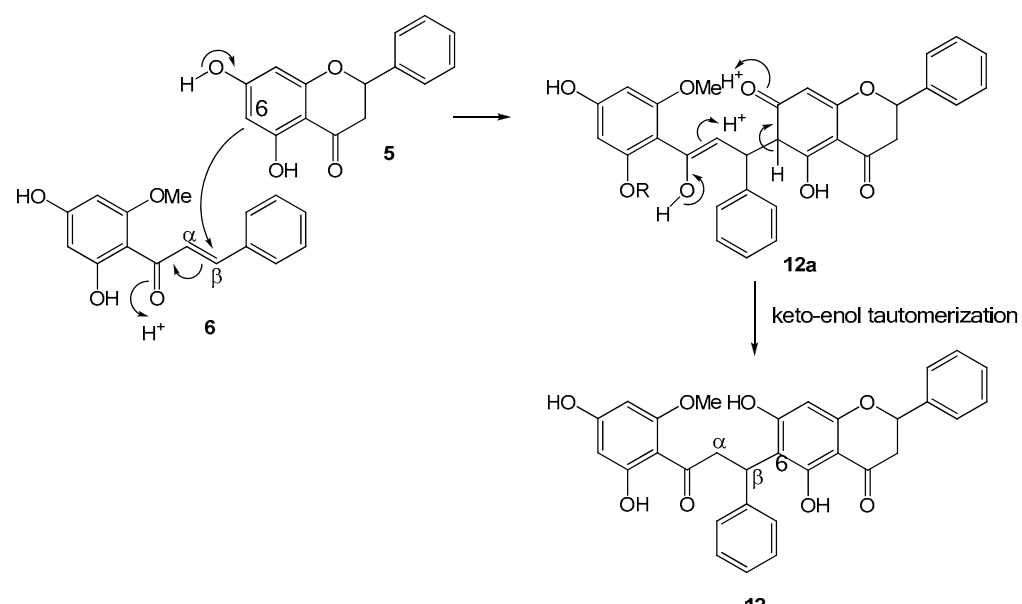

Figure 3. Proposed biogenetic pathway for flavanone-coupled chalcones 9, 12, and 13.

\section{2. $\alpha$-Glucosidase Inhibitory Activity}

Table 2 shows $\alpha$-glucosidase inhibitory activity of Compounds 1-15. Only the cyclohexenyl chalcones $(\mathbf{3}-\mathbf{4}, \mathbf{7})$ and the biflavonoids $(\mathbf{9}, \mathbf{1 2}-\mathbf{1 4})$ displayed significant activity $(>90 \%$ inhibition at $20 \mu \mathrm{g} / \mathrm{mL}$ ), whereas the other compounds were devoid of activity. The flavanone-coupled chalcones $\mathbf{9}$, 12, and $13\left(\mathrm{IC}_{50} 1.3-3.4 \mu \mathrm{M}\right)$ possessed about 3-10 times higher activity than the prenylated chalcones 3,4 , and 7 ( $\left.\mathrm{IC}_{50} 4.6-12.7 \mu \mathrm{M}\right)$. It should be noted that both groups of compounds were much stronger $\alpha$-glucosidase inhibitors than the drug acarbose $\left(\mathrm{IC}_{50} 1.2 \mathrm{mM}\right)$.

To further investigate the inhibitory characteristics of these active compounds, we conducted kinetics studies using Lineweaver-Burk plots of the reciprocal of velocity $(1 / \mathrm{V})$ against the reciprocal of substrate concentration (1/[S]) (Figure 4). Hydroxypanduratin A (7) and rotundaflavanochalcone (9) were selected as the representatives of the cyclohexenyl chalcones and the dimeric flavanone-chalcones, respectively, for enzyme kinetics analysis. The Lineweaver-Burk plots of 7 and $\mathbf{9}$ produced straight lines with intersections on the $x$-axis (the Michaelis-Menten constant, $\mathrm{K}_{m} 0.46$ and $0.47 \mathrm{mM}$, respectively), indicating a non-competitive mode of inhibition. Acarbose, as expected, showed the competitive type of inhibition, with an intersection of the data lines on the $y$-axis. A secondary plot of each compound was then constructed to calculate the inhibition constant $\left(\mathrm{K}_{i}\right)$. We found that both $7\left(\mathrm{~K}_{i} 4.03 \mu \mathrm{M}\right)$ and $9\left(K_{i} 7.19 \mu \mathrm{M}\right)$ showed much higher affinity to the enzyme than acarbose $\left(\mathrm{K}_{i} 167.27 \mu \mathrm{M}\right)$. All these 
results suggested the possibility that these structurally complex chalcones $(\mathbf{3}, 4,7,9, \mathbf{1 2}$, and 13$)$ could be employed as good $\alpha$-glucosidase inhibitors of plant origin. It should be noted that a large number of dietary flavonoids and polyphenols with $\alpha$-glucosidase inhibitory activity have been reported [12], and recently, their synergistic effects with acarbose have been demonstrated [13].

(a)
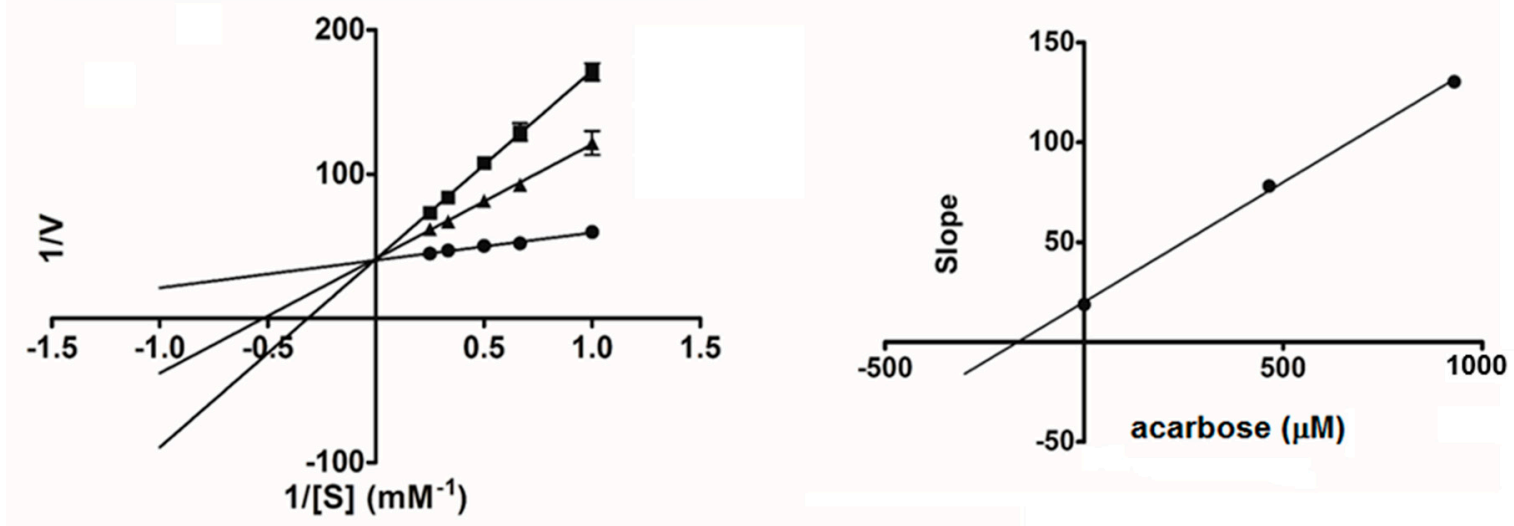

(b)
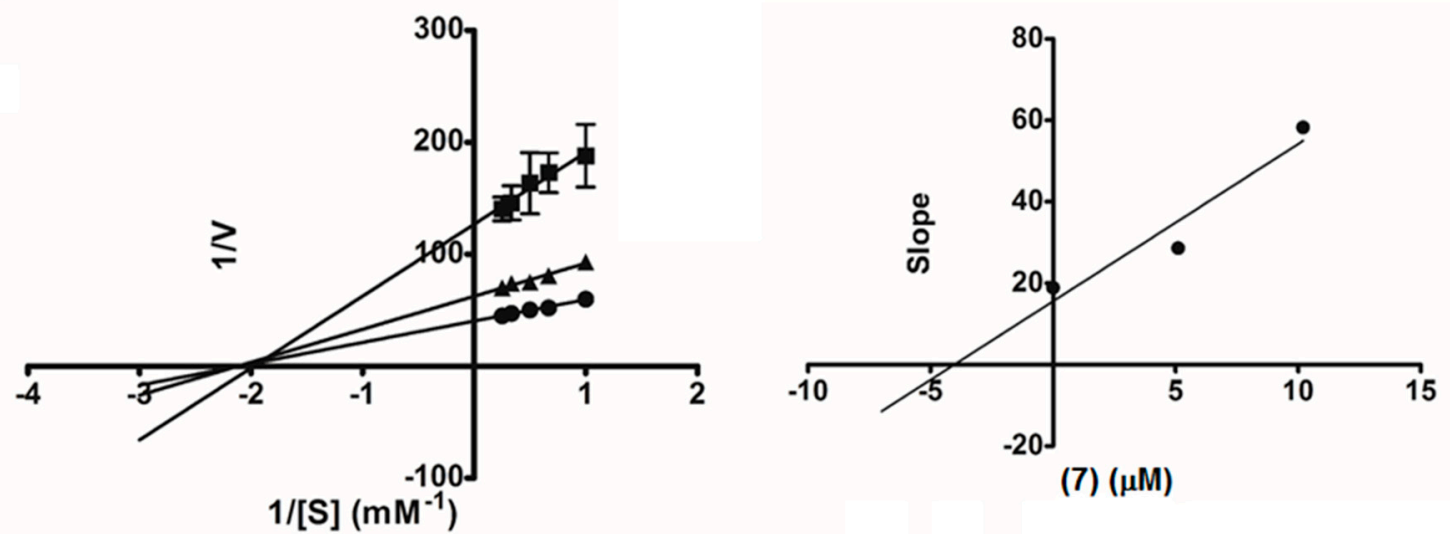

(c)
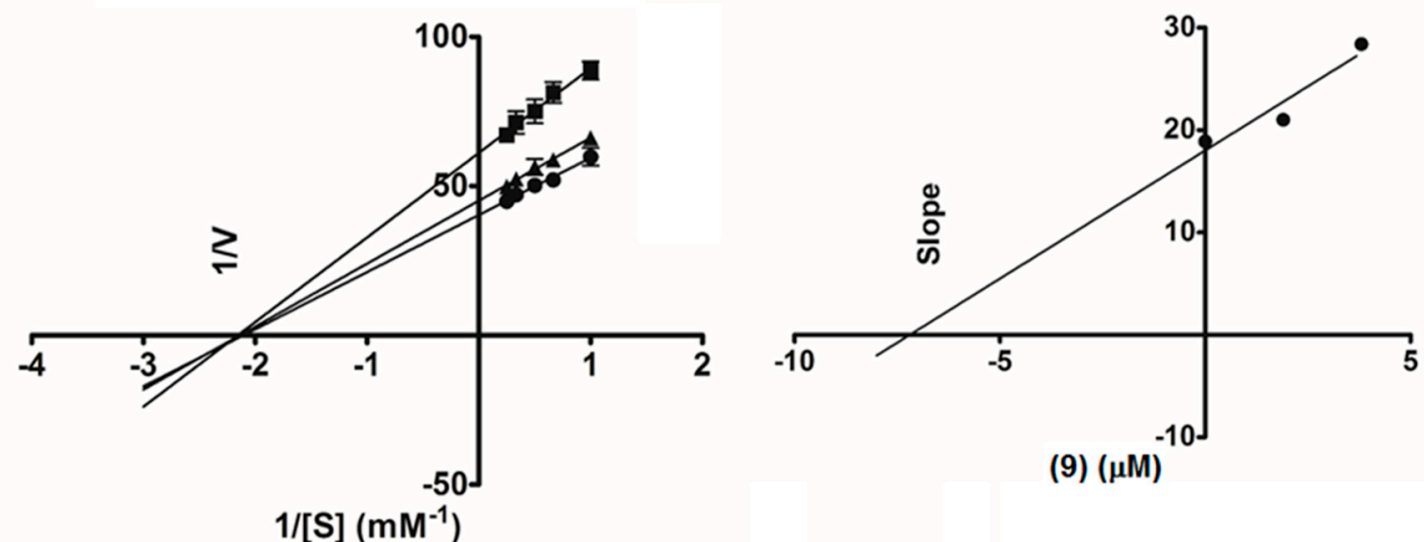

(9) $(\mu \mathrm{M})$

Figure 4. Lineweaver-Burk plots of acarbose (a):

control, $\mathbf{\square}$ acarbose $600 \mu \mathrm{g} / \mathrm{mL}, \boldsymbol{\Delta}$ acarbose $300 \mu \mathrm{g} / \mathrm{mL}$; hydroxypandurantin A (7) (b): • control, $\mathbf{\square}$ (7) $4 \mu \mathrm{g} / \mathrm{mL}, \boldsymbol{\Delta}$ (7) $2 \mu \mathrm{g} / \mathrm{mL}$; Compound 9 (c): - control, (9) $2 \mu \mathrm{g} / \mathrm{mL}, \boldsymbol{\Delta}$ (9) $1 \mu \mathrm{g} / \mathrm{mL}$. The secondary plot of each compound is on the right. 
Table 2. $\alpha$-Glucosidase and inhibitory activities of Compounds 1-15.

\begin{tabular}{|c|c|c|c|c|}
\hline \multirow{2}{*}{ Compound } & \multicolumn{2}{|c|}{$\alpha$-Glucosidase } & \multicolumn{2}{|c|}{ Lipase } \\
\hline & $\begin{array}{l}\text { \% Inhibition } \\
\text { (at } 20 \mu \mathrm{g} / \mathrm{mL} \text { ) }\end{array}$ & $\mathrm{IC}_{50}(\mu \mathrm{M})$ & $\begin{array}{l}\text { \% Inhibition } \\
\text { (at } 20 \mu \mathrm{g} / \mathrm{mL} \text { ) }\end{array}$ & $\mathrm{IC}_{50}(\mu \mathrm{M})$ \\
\hline 1 & $10.0 \pm 2.9$ & - & $7.9 \pm 0.8$ & - \\
\hline 2 & $9.6 \pm 4.0$ & - & $30.6 \pm 2.0$ & - \\
\hline 3 & $94.7 \pm 0.4$ & $12.7 \pm 1.3$ & $72.3 \pm 0.1$ & $17.1 \pm 3.7$ \\
\hline 4 & $97.8 \pm 0.8$ & $7.5 \pm 0.6$ & $75.2 \pm 1.1$ & $15.1 \pm 3.3$ \\
\hline 5 & $19.8 \pm 0.1$ & - & $3.7 \pm 1.3$ & - \\
\hline 6 & $19.7 \pm 0.9$ & - & $7.7 \pm 1.9$ & - \\
\hline 7 & $98.5 \pm 0.4$ & $4.6 \pm 0.4$ & $49.3 \pm 2.7$ & - \\
\hline 8 & $9.5 \pm 2.5$ & - & $33.7 \pm 1.0$ & - \\
\hline 9 & $100.0 \pm 0.0$ & $2.4 \pm 0.4$ & $69.1 \pm 1.6$ & $25.8 \pm 2.6$ \\
\hline 10 & $88.1 \pm 0.9$ & $32.0 \pm 2.2$ & $48.7 \pm 3.5$ & - \\
\hline 11 & $7.0 \pm 2.0$ & - & $8.0 \pm 1.9$ & - \\
\hline 12 & $100.0 \pm 0.2$ & $3.4 \pm 0.9$ & $67.8 \pm 1.3$ & $30.1 \pm 2.3$ \\
\hline 13 & $100.0 \pm 0.1$ & $1.3 \pm 0.2$ & $80.5 \pm 0.6$ & $10.6 \pm 1.2$ \\
\hline 14 & $97.1 \pm 0.5$ & - & $70.9 \pm 2.0$ & - \\
\hline 15 & $20.9 \pm 2.1$ & - & $44.7 \pm 1.7$ & - \\
\hline Acarbose & - & $1155.5 \pm 23.0$ & & \\
\hline Orlistat & & & - & $31.4 \pm 0.6 \mathrm{nM}$ \\
\hline
\end{tabular}

\subsection{Lipase Inhibitory Activity}

Compounds 1-15 were evaluated for lipase inhibitory activity in comparison with the drug orlistat (Table 2). The low percentage of inhibition and high $\mathrm{IC}_{50}$ values of these compounds indicated that all are not potent inhibitors of lipase. However, all the prenylated chalcones and the dimeric flavanone-chalcones $(3,4,9,12$, and 13), except for 7 , displayed recognizable activity. Due to the limited amounts of the isolates, only $\mathbf{4}$ and $\mathbf{9}$ (selected as representatives of the cyclohexenyl chalcones and the flavanone-coupled chalcones, respectively) were subjected to kinetics assays (Figure 5). A Lineweaver-Burk plot of orlistat showed the competitive type of inhibition, with all the data lines crossing the $y$-axis. The plot for 9 displayed $x$-intercept $\left(\mathrm{K}_{m} 0.20 \mathrm{mM}\right)$, indicating the non-competitive mode of inhibition, but the lines obtained for 4 did not intersect either the $x$ - or $y$-axis, suggesting that 4 was a mixed-type inhibitor. The secondary plots generated for 4,9 , and orlistat revealed that the $\mathrm{K}_{i}$ values of 4 and 9 (5.79 and $3.55 \mu \mathrm{M}$, respectively) were far higher than that of orlistat $(7.18 \mathrm{nM}$ ). These data implied that these chalcones $(3,4,9,12$, and 13$)$ had low affinity to the lipase enzyme.

\subsection{Therapeutic Implications}

A recent clinical study has shown that $\alpha$-glucosidase inhibitor drugs ( $\alpha$-GIs) can effectively control blood glucose and body weight in obese type 2 diabetic patients [14]. Thus, the potent $\alpha$-GIs identified in B. rotunda roots, i.e., the prenylated $(\mathbf{3}, \mathbf{4}$, and $\mathbf{7})$ and the flavanone-coupled $(\mathbf{9}, \mathbf{1 2}$, and $\mathbf{1 3})$ chalcones, are good lead molecules or candidates for the development of functional foods for people that are prone to diabetes. Although these chalcones appear to be weak lipase inhibitors, they may well have the possibility of exhibiting anti-obesity activity through other mechanisms. For example, panduratin A (4) has been shown to attenuate high-fat-diet (HFD)-induced obesity in mice by activating AMP-activated protein kinase (AMPK), and this leads to the increase of fatty acid oxidation and inhibition of lipid synthesis $[9,15]$.

Ethnomedicinal data show that people have consumed roots of $B$. rotunda as food for centuries without reports of toxicity [7,8]. Recently, the safety of ingestion of $B$. rotunda roots has been scientifically proven by several in vivo experiments. Biochemical, hematological, and histological parameters obtained for animals fed with $B$. rotunda extracts showed no signs of adverse effects [16-18]. Based on these toxicity studies, occasional consumption of B. rotunda roots extract should be harmless, although the safety of long-term use awaits further study. 
(a)
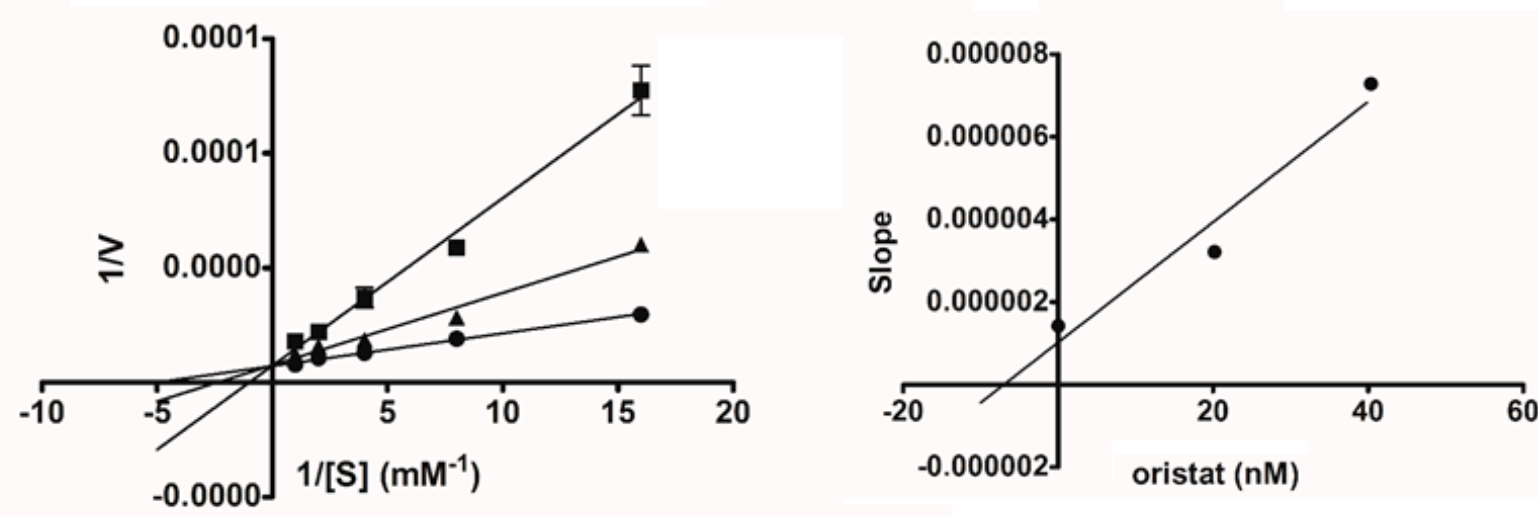

(b)
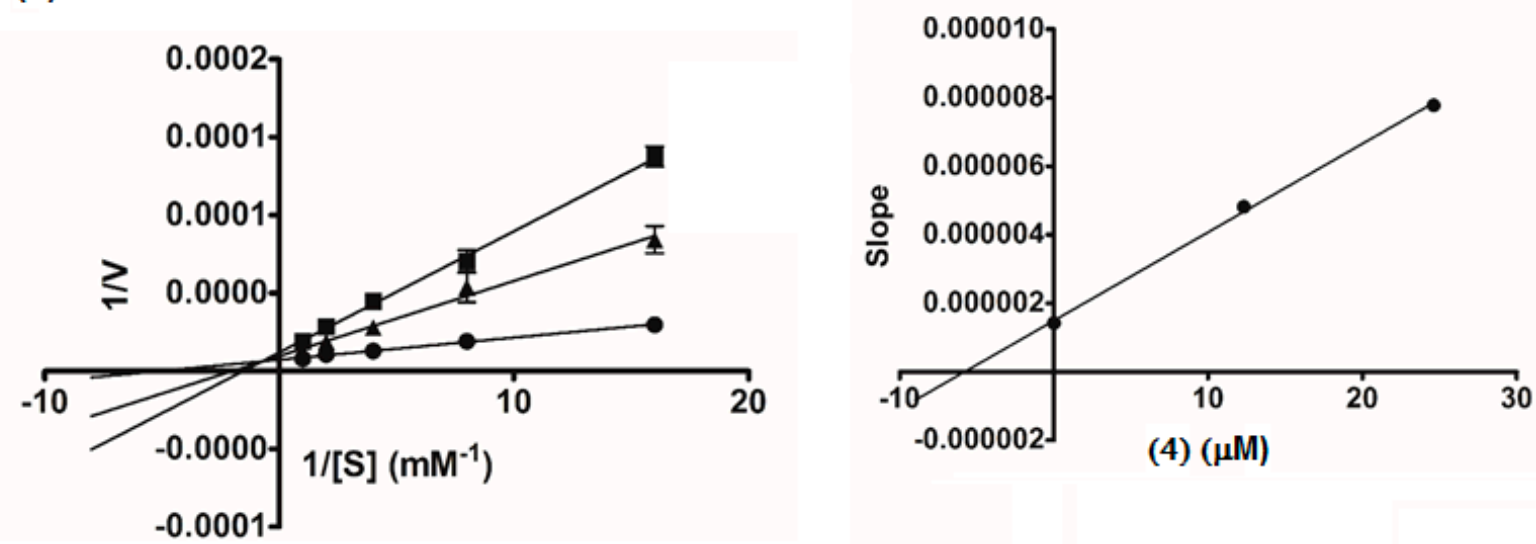

(c)
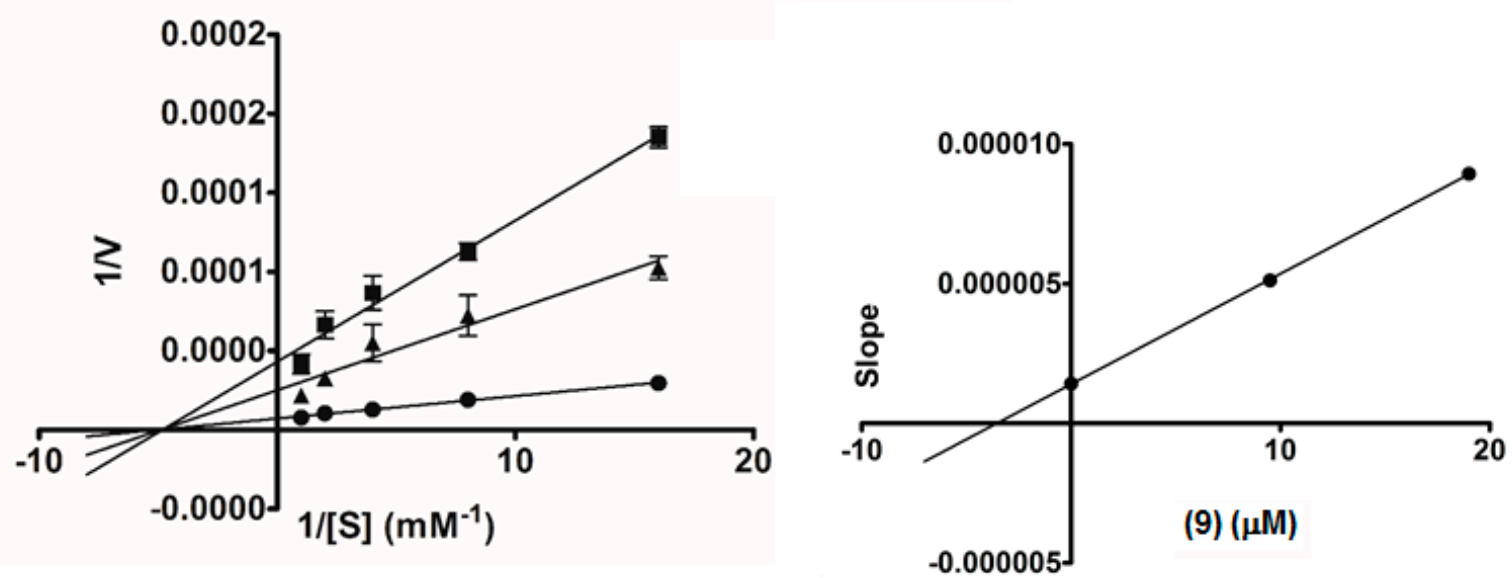

Figure 5. Lineweaver-Burk plots of orlistat (a): control, $\boldsymbol{\square}$ orlistat $20 \mathrm{ng} / \mathrm{mL}, \boldsymbol{\Delta}$ orlistat $10 \mathrm{ng} / \mathrm{mL}$;

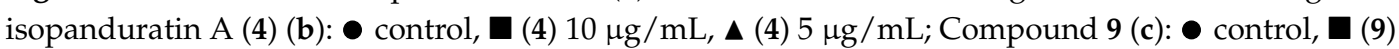
$20 \mu \mathrm{g} / \mathrm{mL}, \boldsymbol{\Delta}(9) 10 \mu \mathrm{g} / \mathrm{mL}$. The secondary plot of each compound is on the right.

\section{Materials and Methods}

\subsection{General Experimental Procedures}

Optical rotations were obtained with a Perkin-Elmer 341 polarimeter (Boston, MA, USA). UV spectra were measured on a Milton Roy Spectronic 300 Array spectrophotometer, and IR was recorded on a Perkin-Elmer FT-IR 1760x spectrophotometer (Boston, MA, USA). High-resolution 
electrospray ionization mass spectra (HR-ESI-MS) were recorded with a Bruker micro TOF mass spectrometer (Billerica, MA, USA). NMR spectra were obtained with a Bruker Avance DPX-300 FT-NMR spectrometer (Billerica, MA, USA). Vacuum liquid chromatography (VLC) and column chromatography (CC) were performed on silica gel 60 (Merck, 70-230 $\mu \mathrm{m}$, Darmstadt, Germany), silica gel 60 (Merck, 230-400 nm) or Sephadex LH-20 (Pharmacia, Piscataway, NJ, USA). Yeast $\alpha$-glucosidase enzyme, $p$-nitrophenol- $\alpha$-D-glucopyranoside, pancreatic lipase, and 4-methylumbelliferyl oleate were purchased from Sigma Chemical, Inc. (St. Louis, MO, USA), and acarbose from Fluka Chemical (Buchs, Switzerland).

\subsection{Plant Materials}

B. rotunda roots were purchased from a local fresh market in Bangkok, Thailand. Voucher specimens (KL-03-2559) have been on deposit at the Department of Pharmacognosy and Pharmaceutical Botany, Chulalongkorn University, Bangkok, Thailand.

\subsection{Extraction, Isolation, and Purification}

Dried roots of B. rotunda $(900 \mathrm{~g})$ were ground and macerated with $\mathrm{MeOH}$ at room temperature $(3 \times 6 \mathrm{~L})$. The filtrate was then concentrated under vacuum to give $84 \mathrm{~g}$ of crude extract. The extract was then treated with $\mathrm{CH}_{2} \mathrm{Cl}_{2}(3 \times 200 \mathrm{~mL})$ to give $\mathrm{CH}_{2} \mathrm{Cl}_{2}$ soluble $(71 \mathrm{~g})$ and insoluble $(13 \mathrm{~g})$ fractions. When evaluated at $50 \mu \mathrm{g} / \mathrm{mL}$, the $\mathrm{CH}_{2} \mathrm{Cl}_{2}$ soluble fraction exhibited about $98 \%$ inhibition of enzymes $\alpha$-glucosidase and pancreatic lipase, whereas the $\mathrm{CH}_{2} \mathrm{Cl}_{2}$ insoluble fraction did not show such activity ( $<50 \%$ inhibition). The $\mathrm{CH}_{2} \mathrm{Cl}_{2}$ soluble fraction was then subjected to vacuum liquid column chromatography (VLC) on silica gel, eluted with hexane/ethyl acetate (EtOAc)/MeOH in a polarity-gradient manner to yield 15 fractions (F1-F15). Fraction 3 (22 g) was recrystallized from a mixture of hexane-EtOAc to give colorless crystals of pinostrobin $(\mathbf{1}, 11 \mathrm{~g})$. Fraction $5(6.6 \mathrm{~g})$ was chromatographed on Sephadex LH-20 (MeOH) to give 12 fractions (F5A-F5L). Fraction F5C (772 mg) was separated on silica gel with hexane-EtOAc gradient elution to yield a yellow oil of geraniol (2, $565 \mathrm{mg})$. Fraction F5G (2.2 g) was separated by silica gel column chromatography (CC) with hexane- $\mathrm{CH}_{2} \mathrm{Cl}_{2}$ polarity gradient elution to give panduratin $\mathrm{A}(3,419 \mathrm{mg})$. Fraction $6(9 \mathrm{~g})$ was subjected to $\mathrm{CC}$ on silica gel (hexane- $\mathrm{CH}_{2} \mathrm{Cl}_{2}$ polarity gradient elution) to give 13 fractions (F6A-F6M). Fraction 6H (600 mg) was further purified by Sephadex LH-20 (MeOH) to furnish isopanduratin A $(4,282 \mathrm{mg})$. Fraction $6 \mathrm{~J}(3.5 \mathrm{~g})$ was recrystallized from a hexane-EtOAc mixture to give pinocembrin $(5,2.7 \mathrm{~g})$. Fraction 7 (2.9 g) was separated by CC on silica gel (polarity gradient elution with hexane- $\mathrm{CH}_{2} \mathrm{Cl}_{2}$ ) to give 18 fractions (F7A-F6R). Fraction $7 \mathrm{Q}(169 \mathrm{mg})$ was further purified by Sephadex LH-20 $(\mathrm{MeOH})$ to give cardamonin $(6,45 \mathrm{mg})$. Fraction $9(3.7 \mathrm{~g})$ was separated on Sephadex LH-20 (MeOH) to furnish 7 fractions (F9A-F9G). Fraction 9B (1.3 g) was subjected to CC on silica gel (polarity gradient elution with hexane-EtOAc) to give 21 fractions (F9B1-F9B21). Fraction 9B7 (507 mg) was further separated by Sephadex LH-20 (MeOH) to give hydroxypanduratin A $(7,24 \mathrm{mg})$ and crude 8 , which was repurified on a silica gel column (hexane- $\mathrm{CH}_{2} \mathrm{Cl}_{2}$ polarity gradient elution) to give 5,6-dehydrokawain $(8,79 \mathrm{mg})$. Fraction $10(729 \mathrm{mg})$ was rechromatographed on Sephadex LH-20 $(\mathrm{MeOH})$ to give 11 fractions (F10A-F10K). Fraction 10J, after removal of the solvent, gave Compound $9(33 \mathrm{mg})$. Fraction $10 \mathrm{~F}(63 \mathrm{mg})$ was subjected to $\mathrm{CC}$ on silica gel with $\mathrm{CH}_{2} \mathrm{Cl}_{2}$-EtOAc polarity gradient elution to give $2^{\prime}, 4^{\prime}, 6^{\prime}$-trihydroxydihydrochalcone $(\mathbf{1 0}, 24 \mathrm{mg})$. Fraction $13(3.7 \mathrm{~g})$ was rechromatographed on Sephadex LH-20 (MeOH) to give 10 fractions (F13A-F13J). Fraction 13C (805 mg), after drying, was recrystallized from a $\mathrm{CH}_{2} \mathrm{Cl}_{2}-\mathrm{MeOH}$ mixture to give alpinetin (11, $\left.219 \mathrm{mg}\right)$. Fraction 13F (267 mg) was subjected to CC on silica gel (hexane-EtOAc polarity gradient) to give 16 fractions (F13F1-F13F16). After evaporation of the solvent, Fraction 13F6 gave Compound 12 (21 mg), and Fraction 13I yielded 13 (12 mg). Further purification of Fraction 13F8 $(56 \mathrm{mg})$ by CC on silica gel with $\mathrm{CH}_{2} \mathrm{Cl}_{2}$-EtOAc polarity gradient elution furnished 4,4',6'-trihydroxy-2'-methoxychalcone (14, $4 \mathrm{mg})$. Fraction $14(1.4 \mathrm{~g})$ was separated on a Sephadex $\mathrm{LH}-20(\mathrm{MeOH})$ column to give 9 fractions 
(F14A-F14I). Fraction 14I (214 mg) was purified by CC (silica gel $/ \mathrm{CH}_{2} \mathrm{Cl}_{2}$-EtOAc polarity gradient elution) to give $7,4^{\prime}$-dihydroxy-5-methoxyflavanone $(15,42 \mathrm{mg})$.

Pinostrobin (1): white solid; ${ }^{1} \mathrm{H}$ - and ${ }^{13} \mathrm{C}-\mathrm{NMR}$ data were identical with reported values [19]; HR-ESI-MS $m / z 293.0781[\mathrm{M}+\mathrm{Na}]^{+}$(calcd for $\mathrm{C}_{16} \mathrm{H}_{14} \mathrm{O}_{4} \mathrm{Na}$ 293.0784).

Geraniol (2): pale yellow oil; ${ }^{1} \mathrm{H}$ - and ${ }^{13} \mathrm{C}-\mathrm{NMR}$ data were in agreement with reported values [20]; HR-ESI-MS $m / z$ 177.1249 [M + Na] ${ }^{+}$(calcd for $\mathrm{C}_{10} \mathrm{H}_{8} \mathrm{ONa}$ 177.1250).

Panduratin A (3): yellow solid; ${ }^{1} \mathrm{H}$ - and ${ }^{13} \mathrm{C}-\mathrm{NMR}$ data were superimposable with literature values [21]; HR-ESI-MS $m / z 429.2032[\mathrm{M}+\mathrm{Na}]^{+}$(calcd for $\mathrm{C}_{26} \mathrm{H}_{30} \mathrm{O}_{4} \mathrm{Na}$ 429.2036).

Isopanduratin $A$ (4): yellow solid; ${ }^{1} \mathrm{H}$ - and ${ }^{13} \mathrm{C}-\mathrm{NMR}$ data were identical with published values [22]; HR-ESI-MS $m / z 429.2038[\mathrm{M}+\mathrm{Na}]^{+}$(calcd for $\mathrm{C}_{26} \mathrm{H}_{30} \mathrm{O}_{4} \mathrm{Na} 429.2036$ ).

Pinocembrin (5): white solid; ${ }^{1} \mathrm{H}$ - and ${ }^{13} \mathrm{C}-\mathrm{NMR}$ data were in agreement with literature values [19]; HR-ESI-MS $m / z 279.0627[\mathrm{M}+\mathrm{Na}]^{+}$(calcd for $\mathrm{C}_{15} \mathrm{H}_{12} \mathrm{O}_{4} \mathrm{Na} 279.0628$ ).

Cardamonin (6): yellow solid; ${ }^{1} \mathrm{H}$ - and ${ }^{13} \mathrm{C}-\mathrm{NMR}$ data matched literature values [23]; (HR-ESI-EMS $\mathrm{m} / \mathrm{z}$ $271.0969[\mathrm{M}+\mathrm{H}]^{+}$(calcd for $\left.\mathrm{C}_{16} \mathrm{H}_{15} \mathrm{O}_{4} 271.0965\right)$.

Hydroxypanduratin $A$ (7): yellow solid; ${ }^{1} \mathrm{H}$ - and ${ }^{13} \mathrm{C}-\mathrm{NMR}$ data agreed with literature values [24]; HR-ESI-MS $m / z 415.1876[\mathrm{M}+\mathrm{Na}]^{+}$. (calcd for $\mathrm{C}_{25} \mathrm{H}_{28} \mathrm{O}_{4} \mathrm{Na} 415.1880$ ).

5,6-Dehydrokawain (8): pale yellow solid; ${ }^{1} \mathrm{H}$ - and ${ }^{13} \mathrm{C}-\mathrm{NMR}$ data agreed with reported values [23,25]; HR-ESI-MS $m / z 229.0852[\mathrm{M}+\mathrm{H}]^{+}$(calcd for $\mathrm{C}_{14} \mathrm{H}_{13} \mathrm{O}_{3} 229.0859$ ).

Compound (9): yellow solid; $[\alpha]_{\mathrm{D}}^{25}-4.1$ (c 0.001, MeOH); UV (MeOH) $\lambda_{\max }(\log \varepsilon): 219$ (4.44), 290 (4.33) $\mathrm{nm} ; \mathrm{IR}\left(\mathrm{CHCl}_{3}\right) v_{\max } 3399(\mathrm{OH}), 2918(\mathrm{C}-\mathrm{H}), 1632(\mathrm{C}=\mathrm{O}), \mathrm{cm}^{-1} ;{ }^{1} \mathrm{H}$ - and ${ }^{13} \mathrm{C}-\mathrm{NMR}$ data see Table 1; HR-ESI-MS $m / z 549.1519$ [M + Na] ${ }^{+}$(calcd for $\mathrm{C}_{31} \mathrm{H}_{26} \mathrm{O}_{8} \mathrm{Na} 549.1520$ ).

$2^{\prime}, 4^{\prime}, 6^{\prime}$-Trihydroxydihydrochalcone (10): yellow solid, ${ }^{1} \mathrm{H}$ - and ${ }^{13} \mathrm{C}-\mathrm{NMR}$ data were identical with reported values [26]; HR-ESI-MS $m / z 259.0965[\mathrm{M}+\mathrm{H}]^{+}$(calcd for $\mathrm{C}_{15} \mathrm{H}_{15} \mathrm{O}_{4}$ 259.0965).

Alpinetin (11): white solid; ${ }^{1} \mathrm{H}$ - and ${ }^{13} \mathrm{C}-\mathrm{NMR}$ data were superimposable with previously described values [19]; HR-ESI-MS $m / z 271.0965[\mathrm{M}+\mathrm{H}]^{+}$(calcd for $\mathrm{C}_{16} \mathrm{H}_{15} \mathrm{O}_{4}$ 271.0965).

Compound (12): light brown solid; $[\alpha]_{\mathrm{D}}^{25}-5.5(c$ 0.001, $\mathrm{MeOH}) ; \mathrm{UV}(\mathrm{MeOH}) \lambda_{\max }(\log \varepsilon): 220$ (4.39), $292(4.33) \mathrm{nm}$; IR $\left(\mathrm{CHCl}_{3}\right) v_{\max } 3391(\mathrm{OH}), 2918(\mathrm{C}-\mathrm{H}), 1631(\mathrm{C}=\mathrm{O}) \mathrm{cm}^{-1} ;{ }^{1} \mathrm{H}$ and ${ }^{13} \mathrm{C}-\mathrm{NMR}$ data see Table 1; HR-ESI-MS $m / z 549.1527$ [M + Na] ${ }^{+}$(calcd for $\mathrm{C}_{31} \mathrm{H}_{26} \mathrm{O}_{8} \mathrm{Na} 549.1520$ ).

Compound (13): light brown solid; $[\alpha]_{\mathrm{D}}^{25}-6.0$ (c 0.001, MeOH); UV (MeOH) $\lambda_{\max }(\log \varepsilon): 204$ (4.04), 219 (4.37), $291(4.28) \mathrm{nm}$; IR $\left(\mathrm{CHCl}_{3}\right) v_{\max }-3398(\mathrm{OH}), 2918(\mathrm{C}-\mathrm{H}), 1632(\mathrm{C}=\mathrm{O}) \mathrm{cm}^{-1} ;{ }^{1} \mathrm{H}-$ and ${ }^{13} \mathrm{C}-\mathrm{NMR}$ data see Table 1; HR-ESI-MS $m / z 535.1365[\mathrm{M}+\mathrm{Na}]^{+}$(calcd for $\mathrm{C}_{30} \mathrm{H}_{24} \mathrm{O}_{8} \mathrm{Na}$ 535.1363).

Helichrysetin (14): yellow solid; ${ }^{1} \mathrm{H}$ - and ${ }^{13} \mathrm{C}-\mathrm{NMR}$ data were identical with reported values [27]; HR-ESI-MS $m / z 309.0739$ [M + Na] ${ }^{+}$(calcd for $\mathrm{C}_{16} \mathrm{H}_{14} \mathrm{O}_{5} \mathrm{Na}$ 309.0733).

4'-7-Dihydroxy-5-methoxyflavanone (15): pale yellow solid; ${ }^{1} \mathrm{H}$ - and ${ }^{13} \mathrm{C}-\mathrm{NMR}$ data were in agreement with reported values [28,29]; HR-ESI-MS $m / z 309.0720$ [M + Na] ${ }^{+}$(calcd for $\mathrm{C}_{16} \mathrm{H}_{14} \mathrm{O}_{5} \mathrm{Na}$ 309.0733).

\subsection{Assays for $\alpha$-Glucosidase Inhibitory Activity}

The assay was based on the capacity of the sample to inhibit the hydrolysis of $p$-nitrophenyl- $\alpha$-D-glucoside (PNPG) by $\alpha$-glucosidase to release $p$-nitrophenol (PNP), a yellow color agent that can be monitored at $405 \mathrm{~nm}$ [30]. Briefly, $10 \mu \mathrm{L}$ of sample solution and $40 \mu \mathrm{L}$ of $0.1 \mathrm{unit} / \mathrm{mL}$ $\alpha$-glucosidase were incubated at $37^{\circ} \mathrm{C}$ for $10 \mathrm{~min}$. Then, $50 \mu \mathrm{L}$ of $2 \mathrm{mM}$ PNPG was added, and the mixture was further incubated at $37^{\circ} \mathrm{C}$ for $20 \mathrm{~min}$. One hundred microliters of $1 \mathrm{mM} \mathrm{Na}_{2} \mathrm{CO}_{3}$ was 
added, and the progress of the enzyme inhibition was monitored by measuring the absorbance at $405 \mathrm{~nm}$. Acarbose was used as a positive control.

\subsection{Evaluation of Lipase Inhibitory Activity}

The lipase inhibitory activity was assessed by measuring the amount of 4-methylumbelliferone (4MU), using 4-methylumbelliferyl oleate (4MUO) as substrate. The assay was modified from a previously reported method [31]. In brief, $25 \mu \mathrm{L}$ of a blank, plant extract vehicle, or a sample solution and $50 \mu \mathrm{L}$ of $0.5 \mathrm{mM} 4 \mathrm{MUO}$ in buffer consisting of $13 \mathrm{mM}$ Tris- $\mathrm{HCl}, 150 \mathrm{mM} \mathrm{NaCl}$, and $1.3 \mathrm{mM}$ $\mathrm{CaCl}_{2}$ ( $\mathrm{pH} 8.0$ ), were mixed in 96-well microtiter plate. Twenty-five microliters of lipase from porcine pancreas (Type II), prepared at $0.5 \mathrm{mg} / \mathrm{mL}$ in the same buffer, was then added to start the enzyme reaction. After incubation at room temperature for $30 \mathrm{~min}, 100 \mu \mathrm{L}$ of $0.1 \mathrm{M}$ sodium citrate ( $\mathrm{pH} 4.2)$ was added to stop the reaction. Fluorescence, corresponding to released $4 \mathrm{MU}$, was then measured with excitation and emission wavelengths of 355 and $460 \mathrm{~nm}$, respectively. Orlistat was used as a positive control.

\subsection{Kinetic Study of $\alpha$-Glucosidase and Lipase Inhibition}

An enzyme kinetic analysis was performed based on the $\alpha$-glucosidase or lipase inhibition assay as described above. The PNPG concentrations varied from 1 to $4 \mathrm{mM}$, and the 4-MUO concentrations varied from 0.063 to $1 \mathrm{mM}$ in the absence or presence of the test compounds for kinetic assays of $\alpha$-glucosidase and lipase, respectively. The inhibition mode was determined by double-reciprocal Lineweaver-Burk plot (1/V vs. 1/[S]). In order to estimate the $\mathrm{K}_{i}$ value, slopes of double-reciprocal lines were used to construct a secondary plot, and $\mathrm{K}_{i}$ was calculated from the line equation of the plot [32].

\section{Conclusions}

The present study investigated $B$. rotunda roots for chemical components with inhibitory activity against enzymes $\alpha$-glucosidase and pancreatic lipase. A total of 15 compounds (1-15) were isolated and structurally determined. Three of the isolates $(9,12$, and 13) are new compounds and form a novel class of biflavonoids. Six compounds $(3,4,7,9,12$, and 13) showed stronger inhibitory activity and higher affinity to $\alpha$-glucosidase than the drug acarbose. The flavanone-coupled chalcones $(9,12$, and 13) had higher activity than the prenylated chalcones (3,4, and 7). Both groups exhibited a non-competitive mode of inhibition against $\alpha$-glucosidase. Some of the compounds isolated from $B$. rotunda presented recognizable inhibitory effects against lipase. Taken all together, the above findings indicate that B. rotunda roots are potential functional food for the prevention or management of metabolic disorders, such as diabetes and obesity.

Acknowledgments: This research has been supported by the National Research University Project, Office of Higher Education Commission (NRU59-004-HR). N.C. is grateful to the Faculty of Pharmaceutical Sciences, Chulalongkorn University for a 2016-2107 postdoctoral fellowship.

Author Contributions: Kittisak Likhitwitayawuid conceived, designed, and supervised the research project, as well as prepared the manuscript. Nutputsorn Chatsumpun performed the experiments and prepared the manuscript. Boonchoo Sritularak contributed analysis tools.

Conflicts of Interest: The authors declare no conflict of interest.

\section{References}

1. Carpentier, Y.A.; Portois, L.; Malaisse, W.J. n-3 Fatty acids and the metabolic syndrome. Am. J. Clin. Nutr. 2006, 83, 1499S-1504S. [PubMed]

2. Grundy, S.M.; Cleeman, J.I.; Daniels, S.R.; Donato, K.A.; Eckel, R.H.; Franklin, B.A.; Gordon, D.J.; Krauss, R.M.; Savage, P.J.; Smith, S.C., Jr.; et al. Diagnosis and management of the metabolic syndrome: An American Heart Association/National Heart, Lung, and Blood Institute scientific statement. Circulation 2005, 112, 2735-2752. [CrossRef] [PubMed] 
3. Bardini, G.; Rotella, C.M.; Giannini, S. Dyslipidemia and diabetes: reciprocal impact of impaired lipid metabolism and Beta-cell dysfunction on micro- and macrovascular complications. Rev. Diabetes Stud. 2012, 9, 82-93. [CrossRef] [PubMed]

4. Graf, B.L.; Raskin, I.; Cefalu, W.T.; Ribnicky, D.M. Plant-derived therapeutics for the treatment of metabolic syndrome. Curr. Opin. Investig. Drugs 2010, 11, 1107-1115. [PubMed]

5. Chuakul, W.; Boonpleng, A. Ethnomedical uses of Thai Zingiberaceous plant (1). Thai J. Phytopharm. 2003, 10, 33-39.

6. Ongwisespaiboon, O.; Jiraungkoorskul, W. Fingerroot, Boesenbergia rotunda and its aphrodisiac activity. Pharmacog. Rev. 2017, 11, 27-30.

7. Eng-Chong, T.; Yean-Kee, L.; Chin-Fei, C.; Choon-Han, H.; Sher-Ming, W.; Li-Ping, C.T.; Gen-Teck, F.; Khalid, N.; Abd Rahman, N.; Karsani, S.A.; et al. Boesenbergia rotunda: From ethnomedicine to drug discovery. Evid.-Based Complement. Altern. Med. 2012, 2012, e473637. [CrossRef] [PubMed]

8. Chahyadi, A.; Hartati, R.; Wirasutisna, K.R.; Elfahmi. Boesenbergia pandurata Roxb., An Indonesian medicinal plant: Phytochemistry, biological activity, plant biotechnology. Procedia Chem. 2014, 13, 13-37. [CrossRef]

9. Kim, D.Y.; Kim, M.S.; Sa, B.K.; Kim, M.B.; Hwang, J.K. Boesenbergia pandurata attenuates diet-induced obesity by activating AMP-activated protein kinase and regulating lipid metabolism. Int. J. Mol. Sci. 2012, 13, 994-1005. [CrossRef] [PubMed]

10. Jayasinghe, U.L.B.; Ratnayake, R.M.S.; Medawala, M.M.W.S.; Fujimoto, Y. Dihydrochalcones with radical scavenging properties from the leaves of Syzygium jambos. Nat. Prod. Res. 2007, 21, 551-554. [CrossRef] [PubMed]

11. Pegnyemb, D.E.; Tih, R.G.; Sondengam, B.L.; Blond, A.; Bodo, B. Flavonoids of Ochna afzelii. Phytochemistry 2003, 64, 661-665. [CrossRef]

12. Xiao, J.; Kai, G.; Yamamoto, K.; Chen, X. Advance in dietary polyphenols as $\alpha$-glucosidases inhibitors: A review on structure-activity relationship aspect. Crit. Rev. Food Sci. Nutr. 2013, 53, 818-836. [CrossRef] [PubMed]

13. Zhang, B.-w.; Li, X.; Sun, W.-l.; Xing, Y.; Xiu, Z.-L.; Zhuang, C.-L.; Dong, Y.-S. Dietary flavonoids and acarbose synergistically inhibit $\alpha$-glucosidase and lower postprandial blood glucose. J. Agric. Food Chem. 2017, 65, 8319-8330. [CrossRef] [PubMed]

14. Sugihara, H.; Nagao, M.; Harada, T.; Nakajima, Y.; Tanimura-Inagaki, K.; Okajima, F.; Tamura, H.; Inazawa, T.; Otonari, T.; Kawakami, M.; et al. Comparison of three $\alpha$-glucosidase inhibitors for glycemic control and bodyweight reduction in Japanese patients with obese type 2 diabetes. J. Diabetes Investig. 2014, 5, $206-212$. [CrossRef] [PubMed]

15. Kim, D.; Lee, M.S.; Jo, K.; Lee, K.E.; Hwang, J.K. Therapeutic potential of panduratin A, LKB1-dependent AMP-activated protein kinase stimulator, with activation of PPAR $\alpha / \delta$ for the treatment of obesity. Diabetes Obes. Metab. 2011, 13, 584-593. [CrossRef] [PubMed]

16. Charoensin, S.; Punvittayagul, C.; Pompimon, W.; Meevatee, U.; Wongpoomchai, R. Toxicological and clastogenic evaluation of pinocembrin and pinostrobin isolated from Boesenbergia pandurata in Wistar rats. Thai J. Toxicol. 2010, 25, 29-40.

17. Salama, S.M.; Bilgen, M.; Al Rashdi, A.S.; Abdulla, M.A. Efficacy of Boesenbergia rotunda treatment against thioacetamide-induced liver cirrhosis in a rat model. Evid.-Based Complement. Altern. Med. 2012, 2012, e137083. [CrossRef] [PubMed]

18. Saraithong, P.; Saenphet, S.; Saenphet, K. Safety evaluation of ethanol extracts from Bosenbergia rotunda (L.) Mansf. in male rats. Trends Res. Sci.Technol. 2010, 2, 19-22.

19. Ching, A.Y.L.; Wah, T.S.; Sukari, M.A.; Lian, G.E.C.; Rahmani, M.; Khalid, K. Characterization of flavonoid derivatives from Boesenbergia rotunda (L.). Malays. J. Anal. Sci. 2007, 11, 154-159.

20. Silverstein, R.M.; Webster, F.X.; Kiemle, D.J.; Bryce, D.L. Spectrometric Identification of Organic Compounds, 8th ed.; Wiley: Hoboken, NJ, USA, 2015; pp. 339-340.

21. Tuntiwachwuttikul, P.; Pancharoen, O.; Reutrakul, V.; Byrne, L. (1'RS,2'SR,6 $\left.6^{\prime} R S\right)-(2,6$-Dihydroxy-4 -Methoxyphenyl)-[3'-Methyl-2'-(3"'-Methylbut-2"'-Enyl)-6'-Phenylcyclohex-3'-Enyl]Methanone (Panduratin-a) - A Constituent of the Red Rhizomes of a Variety of Boesenbergia Pandurata. Aust. J. Chem. 1984, 37, 449-453. [CrossRef]

22. Pandji, C.; Grimm, C.; Wray, V.; Witte, L.; Proksch, P. Insecticidal constituents from four species of the zingiberaceae. Phytochemistry 1993, 34, 415-419. [CrossRef] 
23. Itokawa, H.; Morita, M.; Mihashi, S. Phenolic compounds from the rhizomes of Alpinia speciosa. Phytochemistry 1981, 20, 2503-2506. [CrossRef]

24. Tuchinda, P.; Reutrakul, V.; Claeson, P.; Pongprayoon, U.; Sematong, T.; Santisuk, T.; Taylor, W.C. Anti-inflammatory cyclohexenyl chalcone derivatives in Boesenbergia pandurata. Phytochemistry 2002, 59, 169-173. [CrossRef]

25. Dharmaratne, H.R.W.; Nanayakkara, N.P.D.; Khan, I.A. Kavalactones from Piper methysticum, and their ${ }^{13} \mathrm{C}$ NMR spectroscopic analyses. Phytochemistry 2002, 59, 429-433. [CrossRef]

26. Mustafa, K.; Kjaergaard, H.G.; Perry, N.B.; Weavers, R.T. Hydrogen-bonded rotamers of $2^{\prime}, 4^{\prime}, 6^{\prime}$-trihydroxy-3'-formyldihydrochalcone, an intermediate in the synthesis of a dihydrochalcone from Leptospermum recurvum. Tetrahedron 2003, 59, 6113-6120. [CrossRef]

27. Morimoto, M.; Kumeda, S.; Komai, K. Insect antifeedant flavonoids from Gnaphalium affine D. Don. J. Agric. Food Chem. 2000, 48, 1888-1891. [CrossRef] [PubMed]

28. Dong, H.; Chen, S.X.; Xu, H.X.; Kadota, S.; Namba, T. A new antiplatelet diarylheptanoid from Alpinia blepharocalyx. J. Nat. Prod. 1998, 61, 142-144. [CrossRef] [PubMed]

29. Norbedo, C.; Ferraro, G.; Coussio, J.D. A new flavanone from Achyrocline flaccida. J. Nat. Prod. 1982, 45, 635-636. [CrossRef]

30. He, H.; Lu, Y.-H. Comparison of inhibitory activities and mechanisms of five mulberry plant bioactive components against $\alpha$-glucosidase. J. Agric. Food Chem. 2013, 61, 8110-8119. [CrossRef] [PubMed]

31. Sergent, T.; Vanderstraeten, J.; Winand, J.; Beguin, P.; Schneider, Y.J. Phenolic compounds and plant extracts as potential natural anti-obesity substances. Food Chem. 2012, 135, 68-73. [CrossRef]

32. Rahim, A.T.M.A.; Takahashi, Y.; Yamaki, K. Mode of pancreatic lipase inhibition activity in vitro by some flavonoids and non-flavonoid polyphenols. Food Res. Int. 2015, 75, 289-294. [CrossRef] [PubMed]

Sample Availability: Samples of the compounds are available from the authors.

(C) 2017 by the authors. Licensee MDPI, Basel, Switzerland. This article is an open access article distributed under the terms and conditions of the Creative Commons Attribution (CC BY) license (http://creativecommons.org/licenses/by/4.0/). 